University of Minnesota Morris Digital Well

University of Minnesota Morris Digital Well

2-12-2016

\title{
Musical Athleticism: Victorian Brass Band Contests and the Shaping of Working-Class Men
}

Denise Odello

University of Minnesota - Morris, odell059@morris.umn.edu

Follow this and additional works at: https://digitalcommons.morris.umn.edu/music

Part of the Other History Commons, and the Other Music Commons

\section{Recommended Citation}

Odello, D. "Musical Athleticism: Victorian Brass Band Contests and the Shaping of Working-Class Men." Nineteenth-Century Contexts 38:2 (2016), 141-154.

This Article is brought to you for free and open access by the Faculty and Staff Scholarship at University of Minnesota Morris Digital Well. It has been accepted for inclusion in Music Publications by an authorized administrator of University of Minnesota Morris Digital Well. For more information, please contact skulann@morris.umn.edu. 


\title{
Musical Athleticism: Victorian Brass Band Contests and the Shaping of Working-Class Men
}

\author{
Denise Odello \\ Department of Music, University of Minnesota, Morris
}

In June of 1884, Brass Band News, published an anecdote about an apparent lack of drinking of a small village in Dorset. When the musical rector of the village noted that he "hadn't a drunken man in the village," the author responded by questioning how such a feat was possible. He asked, "Have you no public-house, and is all the village teetotal?" The musical rector answered: “Teetotal! [N]o, not at all; I have a band and choral society, and the members are too busy practicing to find time for immoderate drinking, and the village generally is musical, consequently music, as a means of relaxation and recreation, carries the day." The Dorset rector's faith represents the broader assumption of Victorians that music, in this case both instrumental and vocal ensembles, was not only an outlet for recreation but also an agent of morality, "the true end and aim of music" (2). The British brass band of the nineteenth and early twentieth centuries is a particularly notable example of music as a morally edifying activity, as referenced in the anecdote above. This activity was geared exclusively towards working-class men, and was initially organized and directed by middle-class entrepreneurs and trained musicians. The objectives and rituals of the activity were designed to appeal to working-class men, to address their perceived faults, and to mold them into the image of the middle-class organizers, or at least shape them to fit efficiently into the world that the middle class hoped to create. While music appears to this rector to be an effective means to shape moral habits, the reality is in fact more 
complex: the enthusiasm such pastimes engendered created sites for class conflict and violence even as they sought to conform working class men to middle class values.

Brass bands were primarily organized around one paramount activity: competition. Performance style, tradition, and meaning for participants were all shaped in this particular context. The structure of competition forces an articulation and prioritization of values in order to rank and award groups based on these criteria; successful groups were then emulated, and the values of the competition spread. In the eyes of the middle class, brass band contests were the primary means by which to motivate the working class, who would not otherwise see the value of the exercise, towards musical excellence; curb undesirable tendencies such as violence and drunkenness; and create a cohesive workforce who saw a greater good accomplished through diligent teamwork. Contests were in many ways designed, like sporting activities for students, to shape the work ethic of the participants. The competitive nature of brass band contests makes this analogy especially apt. While the brass band movement of this time period has been well documented, the mechanisms and results of this moral shaping has been studied less thoroughly. ${ }^{1}$ While brass band competitions would appear to encourage moral edification, they became so important and central to the brass band community that conflicts arose when contest results did not agree with the bands or audiences, thus creating a site for the very tendencies the brass bands were supposed to reform; this provides insight into the perspective of the working class, which is notoriously difficult to locate in Victorian cultural products. This article will examine how banding and competition were intended to morally edify participants, what values were promoted through contests, and how the centrality of contests led them to become sites of contention. 


\section{Theory: Brass Bands and Moral Improvement}

Brass bands emerged in Britain towards the middle of the nineteenth century, encouraged, as several scholars have shown, ${ }^{2}$ by contemporary developments in technology, industry, and social conventions of rational recreation. The development of the instrumentation, for example, demonstrates all of these influences. Inventions such as the keyed bugle and later the valve made brass instruments much easier for the amateur to play than their earlier incarnations, and a new industrial infrastructure made the instruments relatively easy to produce and inexpensive. While string and woodwind instruments are somewhat fragile in construction, brass instruments prove more durable. Between the sturdy material used in their construction and the lack of any vulnerable strings or keys, brass instruments could withstand the changing conditions of outdoor performance. Brass instruments seemed to reflect the Victorian image of the working class: valves required little fine motor skill to operate, while string instruments required careful finger placement and woodwinds required the manipulation of multiple keys simultaneously. These rough and hardy qualities of brass instruments, together with their association with military heritage, gave them a particularly masculine appeal. As a result of these technological and cultural circumstances, brass instruments grew in popularity until most bands preferred a fully brass instrumentation.

Brass bands emerged primarily in urban and work-related settings, particularly in the industrial north. The newly-urbanized working population of the north was seen as particularly vulnerable to the lure of the local pub and dance hall, a working-class space during the first half of the century; the healthy pastime of amateur music performance, particularly as structured by middle-class musicians and entrepreneurs, was encouraged at least to a degree in order to dissuade workers from participating in less reputable activities, especially drinking. While bands were associated with 
organizations such as trade union and volunteer movements, in many cases factory owners established groups for workers. A famous example is the Black Dyke Mills Band from Queensbury, Yorkshire. John Foster, the factory owner, initially supplied the group with uniforms, rehearsal space, instruments, and lessons in addition to employment for each member. As Herbert has noted, the necessarily disciplined nature of a band rehearsal routine fit well into newly established work routines of the working class ("Victorian Brass Bands" 112), making it unthreatening to social and economic roles of the time; the ease with which brass instruments could be learned in early stages demonstrated the refined capabilities the middle-class organizers hoped to see realized in the working-class participants.

In competitive settings, brass bands generally performed what would be considered art music, especially selections from operas. Non-competitive performances such as concerts may have a more varied repertoire including dances and marches. At the time, while all music could be considered beneficial, art music was given a special status in its ability to refine both performers and audiences. ${ }^{3}$ In the first third of the century, as brass bands were starting to be established by industrialists and trained musicians for the working classes, writers like George Hogarth made note of music's ability to "soften and purify the mind" (430). One author, the Rev. H. R. Haweis, published a number of works to describe the power of art music specifically in an almost mystical sense, believing music would "help [the working class] to save, it would keep them from drink, it would recreate them wholesomely, and teach them to govern their feelings - to use, and not invariably abuse, their emotions" (Memories 82). One of his works, Music and Morals, was reprinted 21 times by 1906, testifying to the power of this idea among the literate public. His words carried weight with middle-class brass band enthusiasts as well; the editors of Brass Band News reprinted Haweis's 
words in their July 1887 issue. For some, the amateur performers and occasionally mixed repertoire of the brass bands made them less perfect vessels of music culture. Contemporary commentators in brass band periodicals noted that brass bands were accomplishing the noble goal of bringing art music to the masses, albeit not as ideally as professional and mixed brass and woodwind military bands would: "I say, certainly let us have our brass bands, rather than none at all, they are at any rate infusing a love of music and a knowledge of the art amongst a class of the community; but, how much greater would be the result, if good and well organized military bands were heard more frequently in our midst" (October 1890, 291). The bands, therefore, were meant to operate in a morally beneficial manner in one sense by not only by instilling a love of art music and discipline in the band members, but also by exposing a large portion of the working-class population to music which they would not have heard normally, although in a less perfect mode. The same idea was at work in the concerts of Jullien, who mixed popular appeal and art music to attract a broad audience (Raynor 103-4). The common sense of the time would seem to indicate that some Mozart, albeit creatively arranged and packaged into a brass band piece and perhaps performed alongside a quickstep at a concert, was better than no Mozart at all.

While middle-class Victorians were clearly motivated to organize bands by the morally edifying properties of music, they did not believe such motivation would necessarily appeal to the working class. The required motivation would be found in the public activity of competitions; I will expand further on this motivation below, but a brief overview of contest development is in order here. Capitalizing on the new, popular hobby of "banding," event organizers began to include brass band contests in their planned spectacles. Local celebrations began to feature bands. The earliest reported example occurred in 1845 at a Magdalen festival at an estate outside of Hull in 
Yorkshire. ${ }^{4}$ Five bands participated, a mixture of workplace-related groups and community groups. Eventually the band contest became a self-sufficient event that stood on its own. One audience member at the Magdalen festival, Enderby Jackson, later discussed the possibility of a large-scale event with two other band masters at the 1851 Exhibition, and the plan came to fruition at the Crystal Palace at Sydenham in 1860. Jackson introduced a key component that would allow brass band contests to flourish; he worked with railway companies to secure inexpensive railway day excursions for bandsmen and their supporters, using the newly-expanded railway system to bring bandsmen and spectators from throughout the industrialized north to the contest in London. The second day of the event alone attracted 22,000 spectators. The Belle Vue Zoological Gardens outside of Manchester, the pre-eminent leisure park for the middle class of the north, began featuring an annual contest in 1853. According to a biography of Belle Vue founder John Jennison written by his grandson George, the attendance for the first contest was more than 10,000 people (101). A review from the Manchester Guardian was clearly impressed: "[A]ll the bands comprising 100 brass instruments, united by pre-arrangement in the performance of our heart-stirring national anthem. Such an effect has rarely been witnessed ... a profound silence was observed by an audience composed of nearly 10000 people, who stood or sat uncovered, whilst the impressive strains poured forth" (September 10 1853, 7). By the last quarter of the nineteenth century, brass band contest had proven to be a sound financial venture, and an event that fit into Victorian notions of working class identity, the uses of music, and love of spectacle.

The competitive aspect of brass bands lends itself to a comparison to sport, an activity best known for competition encouraging excellence. An examination of the social mechanisms of sport reveal how these same motivations operate in brass band 
contests. The contextual similarities between sport and brass banding underline the forces shaping both; similar trends occurred in both areas, most notably formalization and codification. As the nation urbanized and the workday and week codified, sport followed suit. Activities that had been informal gatherings now required formalizing as life became more regulated. Sport was relegated to the weekend, more specifically Saturday afternoons, codifying the appropriate time for sport activity. Interest in particular sports was regulated nationwide; national championships were instituted for previously regional interests, such as lawn tennis and golf. Professional sport and regulating bodies emerged during this time, and audiences increasingly gathered to see others engaged in a high level of athletic endeavor. For example, the average attendance at English county cricket matches rose from around 4,000 in the 1860 s to up to 24,000 in the early 1900s, depending on the location and importance of the match (Tranter 17). This expansion was made possible by the developing rail system, the same industrial innovation that made national brass band contests possible. As the century progressed, this trend of codification and formalization continued: spaces for sport were fenced in, structures to contain sport were built, and a system to monetize sport by charging spectators and compensating players and employees grew. The brass band contest, especially at the national level as represented by the Crystal Palace contests and Belle Vue contests, is directly analogous to this formalization in sport.

Concurrent to this spread and codification of sporting ritual was the expansion of varieties of sport to new social classes. Certain sports such as soccer and cricket spread from upper-class participants and became part of working-class life. A number of authors, including Mangan, find this to be evidence of a diffusion of sport from the top of the social order down. This diffusion does not act as a control mechanism, or a space for participants to vent violent tendencies; rather, sport provides instruction as to 
how to channel these impulses and shape the working class in terms of middle-class masculinity. Mangan most succinctly presents these goals as "physical and moral courage, loyalty and cooperation, the capacity to act fairly and take defeat well, the ability to both command and obey"(Athleticism 9). For the working class, these values were expected to create loyal subjects, populations who could fit easily into the world scheme of the middle class and not be disruptive to social order. In this sense, attempts to mold the working class were more akin to the shaping of colonized populations. In his book Manufactured Masculinity, Mangan presents sport, such as soccer, in the empire as moral training:

(T)he game was considered ... to carry with it a series of moral lessons, regarding hard work and, indeed, involving concepts of correct physical development and "manliness." As such, it was used as a key weapon in the battle to win over local populations and begin transforming them from their "uncivilized" and "heathen" state to one where they might be considered "civilized" and "Christian." (409)

These are precisely the same values that the middle class hoped to develop in workingclass musicians, another group that need to be transformed from "uncivilized" to "civilized," through the unique context of competition. In addition to the benefits of art music, the presentation of music in a specifically competitive setting could reinforce the morals of hard work earning a reward, sportsmanship, and loyalty to your group.

Two particular tendencies in the working class that brass banding was hoped to temper were violence and drunkenness. Hogarth noted that music offered the working classes "a relaxation from toil more attractive than the haunts of intemperance" (430), indicating the role of musical activities with regard to drink. The Temperance movement of the 1840 s is certainly a testament to the general Victorian anxiety over the consumption of alcohol. While leisure was seen as a necessary release from the 
pressures of life, increasingly the middle class saw recreation in a pub as associated with working-class rough manners and drunkenness. ${ }^{5}$ Music halls were primarily working-class venues during the first half of the century due to their proximity to pubs. In Victorian assessments of working-class life, middle-class authors expressed dismay at leisure activities that involved physical excess: feasting, fighting, sex, and above all drunkenness. In his discussion of working class respectability, Bailey states that employers were shocked and dismayed when they discovered that their employees drank. He cites William Sargant, a manufacturer from Birmingham; the businessman asserts his ignorance of his laborer's habits, and admits that "We see them in their places during the day, we find them always ready to labour when they are called upon, and we set them down as men of temperate habits... it is sometimes startling to find that we are entirely mistaken" (Leisure and Class 54). In some cases brass bands, similar to Working Men's Clubs, reflected employers taking an active role in the leisure of the workers, and were meant to discourage drinking through alternative pastimes that did not allow for such vices. While brass instruments could be considered less demanding in terms of fine motor skills than woodwinds or strings, they still require coordination and focus, theoretically discouraging the use of alcohol during musical pursuits.

Violence was the other primary concern that both banding and sport addressed. The working class man was certainly perceived as predisposed to violence, and accordingly in need of activities to structure their leisure. ${ }^{6}$ The middle-class anxiety about working-class violence was demonstrated through a variety of means in Victorian life, both in thought and action. ${ }^{7}$ It appeared in literature and was reflected by middle class populations retreating into suburbs and their ensuing efforts to limit working-class presence. This propensity to violence appears as well in depictions of brass bands; however, it is generally presented as tempered by the good influence of refined music. 
One of Dickens' journals, Household Words, noted the brass band phenomenon in 1850 , stating that art music had "of late years been descending from the higher to the humbler classes." The author then goes on to describe the laborers as "peaceful and simple," and cites a local source as saying "During a stay of several weeks in the town ... I neither saw nor heard of altercations or fighting" (May 11, 161-2). While a brass band contest was not a physical outlet in the sense that sport could be, it clearly appeared to the middle-class mind to fulfil the need to curb violence. However, the contest in reality proved to actually be a site for conflict, undermining this ideal.

\section{Practice: The Brass Band Contest and Codification of Tradition}

Contests become the primary context for brass bands; they are a space where musical practice is not only regulated, but becomes regulating. The formalization and codification that is seen in Victorian sport occurs in brass band tradition through competition. The prevalence of competition among brass bands leads one to consider banding as sport as much as art. The impetus to organize these competitions is described in contemporary sources as arising from a desire to shape the working classes through art music, as well as a need for external motivation for working-class musicians. Enderby Jackson, the self proclaimed inventor of brass band contests, saw music as imperative to improving the masses and competition the way to motivate working class participants who otherwise would not be inclined to musical practice, citing conductor Louis Antoine Jullien and his extensive touring and performances of Western art music as inspirations. Jackson professed in his unpublished autobiography that the conductor "did more to humanise and make happy the homes of the middle and poorer classes of England than any man of our times professing social reforms...I have followed in his footsteps, my life has been one of devotion... to propagate that which I love; the humanising power of music over all frail human passion" (2). Jackson then links the 
concept of a brass band contest to prizes given at an agriculture show, as he witnessed the enthusiasm of the participants. Jackson recounts: "I saw the excitement produced. Was it entirely to see the horses run the people cared for? No, thought I, it is the rivalry; and if this rivalry could be instituted amongst workmen with music instead of horses, my work would be inaugurated" (Autobiography 5). Early band contests, such as those held at the Crystal Palace in the 1860s and the Belle Vue contests of the 1850s, were certainly organized as much for raising revenue as they were for driving musical improvement, but the educational tone of the activity remained. It was geared towards a poorer class who needed "humanising" through music.

The argument for the necessity of contests continued to be discussed in literature geared towards bandsmen. These periodicals can be difficult to dissect with regards to class; while it can be assumed that the editors and many contributors were middle class, some contributors more clearly identify themselves as working class, discussing working-class concerns and using language to identify themselves. ${ }^{8}$ The majority of discussion on contests and their use seems to come primarily from middle-class voices, emphasizing the use of contests to improve musical quality. A trained musician and central figure to the brass bands of the early twentieth century, J. Ord Hume, wrote in British Bandsman on rural groups and the importance of contests in this manner: "Suffice it to say that the village band is gradually, but surely, improving, and if contesting could only be brought about it remote parts, the bands would awaken to a new lease on life. Contesting is, in my opinion, the only way in which to raise the standard of moderate bands which have got so far and no further" (February 1899, 41). Another strain of the argument focused on audience; while bands of working-class musicians could become very adept, working-class audiences would not necessarily be able to tell the difference. Only trained musicians would be able to correctly identify 
musically excellent bands through the contest. Another editorial in Brass Band News described the situation this way:

Now, a band that never played a tournament may be a good band; but as the inhabitants of the place, as a body, are not musical, or at least not critical, the band is in some measure "wasting its sweetness on the desert air," for it gets no more praise or consideration than a much inferior band. But let that same band attend a contest and come home successful, and what a difference! All are ready to join in the chorus, "See, the conquering heroes come." The bandsmen now feel that they have a band to be proud of, and henceforward both the musical and unmusical inhabitant will identify the interests of that band with his own. (December 1890, 5)

According to this line of thinking, band contests both motivate participants and shape the taste of working-class and rural audiences, who cannot identify musical value unless it has been marked for them through competition. Contests therefore work to improve taste in both band participants and unrefined audiences.

The bandsmen themselves embraced the concept as well, and to such a degree that they came to regard contests not as simply one venue for brass bands, but the primary venue. While prevalent notions of respectability, masculine camaraderie, and self-improvement were motivations to join brass bands, competitive gatherings offered a more immediate and satisfactory reward for the effort. Contests offered prizes such as instruments and monetary rewards to the groups who placed highly in the rankings; as some bands became more proficient at contest performance, the members became accustomed to the supplementary income the prize money provided. Bands that did not compete and focused on concerts were considered inauthentic to a degree. Smaller bands that were not as consistently successful viewed contests as a matter of pride, and a good showing was, as the Brass Band News predicted, usually rewarded with a hero's 
welcome when they returned home. By the end of the nineteenth century the centrality of the contest was such that an author in the Brass Band News could declare, "Any of the crack bands will accept an engagement to play two or three concerts on succeeding days, and will give satisfaction without having a single rehearsal. But will any of these bands go to a contest without a rehearsal? ... We know that they would not." The author states that a band's reputation is built on the contest field rather than a concert hall, and gives specific reasoning for this circumstance: "The Briton loves a fighter, and he adores a successful fighter. That is why contesting bands are generally so much better treated... than other bands are" (August 1899, 4). The continued interest in contests would appear to corroborate the author's reasoning; the fighting that would erupt as a result of unpopular contest results was a less desirable manifestation of this "fighter" ideal. While this is not a direct statement from working-class participants, this shared assumption that shaped performance practice indicates how prevalent the centrality of the contest was to bandsmen.

An example of the cultural trajectory by which contests came to eclipse concerts in importance can be seen in the history of one of the most enduring and popular brass bands, the Besses o' th' Barn. The band originated as early as 1818 as the Cleggs Reed Band, associated with a cotton mill; later, the group was no longer associated with the mill and relied upon community involvement through subscription to keep operating. As a subscription band, its members were drawn from the immediate community primarily, rather than from a particular workplace. Around 1860, perhaps earlier, the band transitioned to an all-brass configuration, as many bands did after all-brass bands began to dominate band contests of the $1850 \mathrm{~s}$. The group had throughout its short history performed in many settings throughout the community, but the new all-brass configuration indicated the band's goal: a prize at a competition, specifically the Belle 
Vue contest. The group hired James Melling, who had helped plan the Belle Vue contest before the inaugural competition, to conduct and prepare the band. This led to two fourth place showings, but no championships. In 1879 the group hired another conductor, John Gladney, who had led the Meltham Mills band to Belle Vue success; again, no Belle Vue championship. Alexander Owen was then hired, and would be associated with the band for over 35 years. All of these conductors were hired specifically for their proven experience in winning contests. In particular, a poor showing at a contest precipitated the hiring of Owen; being reliant on the community for support, it was the community who desired a better contest result and collected funds for the effort. Joseph Hampson, author of a short history of the band, details the contributors' intentions as "determined if possible to raise a band that should hold its own against all comers, doing credit to themselves and neighbourhood as well" (32). These concerns are strictly competitive and do not reflect interest in refining locals through the performance of art music. As a result of this recruitment, the band began to win first prizes in smaller competitions, but it was not until 1892 that the group won a first prize at Belle Vue.

The band was distinct in that it was particularly active with concerts and touring. During Owen's tenure especially the band played concerts both during contest season and out of season, as can be seen in periodicals that reported on the events such as Brass Band News. Concerts were especially attractive as they could play many of Owen's special arrangements, like Reminiscences of Rossini, multiple times. Contests such as Belle Vue used test pieces, typically arranged specifically for that contest, and fans of competing bands began to surmise that Besses' lack of competitive success was due to its repeated repertoire: "it has been said if you put their instruments on a stage, and blew them after the manner of a hobby-horse organ, they would tootle the same old tune" 
(Brass Band News December 1887, 7). The money they commanded for performances caused doubt as to their "amateur" standing. It was not until their 1892 championship that they became a serious brass band in the eyes of fellow competitors again. An article appearing in Brass Band News (November 1894, shortly after another Belle Vue victory) focusing on the band spent nearly half of the space describing the band's contest successes, including a table to compare their number of prizes and earnings with the other top bands of the time such as Black Dyke and Kingston Mills. Competitive standing was the prime measure of a band among brass band enthusiasts; concert success was a secondary consideration.

The centrality of the contest and the importance attached to competitive standing meant that fairness in competition was of utmost importance; a central topic of discussion around contests, as in sport, was the idea of fair play, allowing bands to compete on an equal field in order to truly allow the best ensemble to prevail. In terms of athleticism and education, Mangan sees fair play as a concept that needed to be learned: “'Fair play' was not the instinctive behaviour of gentlemen but the acquired behaviour of roughnecks... It was cultivated carefully as a practical tool... It was a means of ensuring controlled competition in physical struggles on the new playing fields" (101). While this perception may have endured among the middle class, in some contexts evidence exists that "fair play" was already a value in working class life. John Archer, in his discussion of masculine violence in the Victorian period, sees the concept of a fair fight as prominent in working-class practice: "Working-class combatants possessed their own codes of honour and manner of fighting known as 'the fair fight' or 'up and down fight'. The crucial ingredients were that the fight was mutually agreed upon, no weapons were used, and that only two combatants were involved" (159). Combining a middle-class tendency to see a need to instil fair play with the working- 
class value of the "fair fight," this level playing field would be of primary importance in the brass band contest. Over the course of the second half of the nineteenth century, regulations grew to astonishing complexity. ${ }^{9}$ Although a national organization overseeing all competitions failed to materialize, certain prominent competitions, especially at the national level became blueprints on which regional competitions could base their own regulations, thereby regulating contest practice to a degree. The Crystal Palace and Belle Vue competitions mentioned above had the most effect on contest regulations. From the inception of the contests, amateur standing was of particular importance; additional aspects of contests, such as instrumentation and repertoire, became more regulated as well to ensure a "fair fight."

The regulations of many contests reflect the importance of amateur players; this became an increasingly urgent concern as the century wore on, some bandsmen became especially proficient musicians, and victory at contests became more central to a band's status. Regulations at the early large competitions, Belle Vue and the Crystal Palace competitions of the $1860 \mathrm{~s}$, emphasized a player's amateur status. For example, the Crystal Palace competitions required bands to submit applications that listed the occupations of each band member in addition to their instrument; one band, Meltham Mills, listed professions such as stone mason, wood turner, mechanic, and cotton twiner in their 1860 competition entry form (Massey 4-5). Later regulations would also stipulate that players be qualified as "bona fide," meaning that they had been a member of the band for a given length of time. This developed as proficient bandsmen began to be recruited for other bands, given employment to qualify for the group, and thus attained a "ringer" status. Brass Band News published suggested contest rules in 1881, and can be regarded as a statement of general practices for the time. Their "bona fide" regulation stated "All the performers must be members of the particular band in which 
they are entered, and not selected from other bands; (two months' membership to constitute a member;) no member, on any consideration whatever, will be allowed to play in any other than his own band" (December 1881, 1). The distinction between amateur and professional proved problematic to maintain, as well be detailed further below.

Regulations affected repertoire as well. In order to assure the fairest musical fight possible, Belle Vue developed the idea of a "test piece," or a piece of music that every band would perform. In the 1855 Belle Vue competition, all groups were required to perform James Melling's composition Orynthia along with a selection of their own choosing. In 1867, the band's choice piece was eliminated, and everyone was judged solely on the performance of a test piece. At the Belle Vue competition, a contest that had a national draw and was considered elite, the most common test pieces were arrangements of art music, often opera. After Belle Vue adopted this practice, other contests followed suit. Regional or local contests might require a test piece that was considered less demanding, such as an arrangement of popular tunes or a "quickstep." During competitions, judges were ensconced in a listening booth, where they listened to each band without any idea of what bands performed in the order, in an attempt to avoid partiality. Brass Band News weighed in on the value of the test piece as well in 1882, by which time it had become a prevalent practice:

[On the] subject of musical competitions held during the last year, we find the most successful ones have been those where the promoters have provided a 'set' piece, which test the powers of each band both individually and collectively, and enabled the judgement to be made on the only fair and equable basis, i.e., the same difficulties and the same 'points' applied to one and all. (January 1883)

After a band with an all-brass instrumentation won first prize at Belle Vue in 1853, bands began to convert en masse to that format, as seen earlier with the Besses o' 
th' Barn. The instrumentation was formalized later in regulations, again in the interest of an even playing field. A specific incident occurred at the Belle Vue competition, where a challenging solo was performed on a valve trombone rather than a slide instrument, thus making the technical challenges of the solo easier to tackle. One bandsman, Ben Haley, recalled the incident for Brass Band News in a series about Belle Vue:

In 1873 I played with Elland Edge Band at Belle Vue ... The piece was "Dinorah," and I was to take a portion of the euphonium solo while the regular euphonium player took the valve trombone from the trombone player and played the cadenza for him. But we did not get in the prizes that day. Phineas Bower did the same trick the same day, but he came off better, for he got the special prize for best euphonium, and also the special prize for best trombone, and the band he played with (Black Dyke) got $3^{\text {rd }}$ prize. When this was found out after the contest that Phinny had got both prizes he was asked to return one, but he was a true bred Yorkshireman and stuck to both. That was the last time valve trombones were allowed at Belle Vue, and the last time anyone was allowed to play on two instruments. (November 1904, 4)

At the time, players were allowed only to perform on one instrument; Bower allegedly smuggled a cornet in his jacket and had a cornet player bring the trombone onstage for him. Bower's response to the organizer's request to return one prize, and the way that Haley frames it in his recounting of the event, points to some of the discrepancies that arose in the practice of brass band contests as a morally improving activity: the practice did not always yield the desired results.

\section{Disruption: Contests as Contested Space}

The didactic nature of rational recreation practices like brass bands led to some working-class resistance to activities. While it is difficult to find these opinions 
recorded in prose form, the type of participation (or non-participation) of working-class representatives can indicate how the intentions of such activities were received. One example cited by Bailey, Samuel Greg, set up a wide variety of pastimes for his workers, but observed that his employees often were "not sufficiently cultivated" to desire to participate in some of these activities, and recommended "gently leading them" in order to "at length succeed in making them what you wish them to be" (Leisure and Class 42-3). However, requirements for participation in these schemes, generally of conduct and appearance, kept laborers away. A decade after Samuel Greg had introduced his improvements for his employees, he was thoroughly disappointed when they went on strike in 1847 over the introduction of a new manufacturing process without any attempt of negotiation. They did not appear to appreciate his efforts at cultivation.

As the nineteenth century turned into the twentieth, the brass band contest transformed into something more complicated than what its initiators had imagined. Working-class bandsmen had embraced the ritual; they had embraced it to such a point that some of the aspects of the working class that the activity was supposed to reform, such as violence, were actually sparked in the heat of competition. The class structure that pervaded brass band contests, a middle-class organization for working-class participants, was also threatened by the shifting status of especially adept musicians who rose from a working-class status to equal to the trained musicians who conducted and judged them. Finally, as the movement transitioned into the twentieth century, the activity abandoned its morally-edifying origins and became somewhat insular, developing its own literature and canon or repertoire.

The complexity of the relationship between brass band contests and the goals they were to accomplish manifests itself in early commentary, which highlights the 
working-class nature of the participants, and their perceived proclivities. A notorious example can be found in Charles Dickens' journal All the Year Round. A feature from November of 1859 recounts a local brass band contest. This date is early enough that the codification of contests through national examples had not yet occurred, and regional contests were largely informal. The author reinforces the connotations of the working class and drink, contrary to the idea that music would lead participants away from alcohol; he states that he witnessed "the first band that had come into Lofthouse to try its musical skill, very busily engaged in trying the Lofthouse rum and ale; while, hanging up by hooks from the ceiling, amongst many bundles of dried winter herbs, were several cornopeans to be used in the harmonious fight." While the author is clearly skeptical of the abilities of the laborer musicians throughout the piece, he does finally concede that while "To say that the performance of these difficult pieces approached perfection, would only convey an untruth, ... it far exceeded the ordinary standard of civilisation existing at the place from which the bands were drawn." The author is also persuaded that brass bands may be a remedy to violence, although with conditions, and clearly marking the class of his subjects:

I do not pretend to say, that because Ah, che la morte! is blown upon a Yorkshire trumpet, fighting is altogether a stranger to Yorkshire fists, but I think that the man who conducts the melodies of Bellini, although in a crimson waistcoat and coduroys, is not likely to bite off his neighbour's ear, and is very likely to have a humanising influence on some of his less cultivated brethren, besides.

The author's admiration is won when the laborers have exceeded their class limitations through their musical practice; however, the limitations remain, and the results of this molding activity are mixed at best.

As with other examples of sport and competition, the stakes that are associated with success can lead to behavior that falls short of the ideals of "the capacity to act 
fairly and take defeat well" (Athleticism 9) as stated by Mangan. When the verdict of the judges did not meet with the approval of the bandsmen or their supporters, the objections were loudly voiced. Stories abound in Brass Band News and the British Bandsman of dishonorable behavior on the part of bandsmen when a call was not made in their favor. A report from Brass Band News of July 1893 states that a judge was attacked by members of a slighted band, along with others: "Members of the Wyke Band were particularly anxious to get at him, and he was alleged to have been severely kicked by the defendants about the lower part of the body. He had to be locked up in a greenhouse for safety, and was eventually taken to the station in a cab to elude his assailants" (7). In discussing the uses of violence in the Victorian period, Archer frames conflicts with authority figures as perceived threats to masculinity; violence, no matter what the outcome, was seen as a means to preserve ones role as a man. This code of acceptable violence between men was seen as tolerable more in the working classes than in the middle classes, who increasingly frowned upon such displays during the course of the nineteenth century.

Various contributors routinely condemned such violence at brass band contests in the pages of band periodicals. One commentator, going by "Mr. Sparks," advised the editors of the periodical to avoid the judge's tent, "carefully guarded by one or two stalwart policemen" and to pity the adjudicator within (British Bandsman July 1888, 184). The situation led to established judges leaving the banding world altogether, such as Charles Godfrey, a military bandmaster who judged at major competitions for nearly two decades between 1872 and 1888. Another commentator in the British Bandsman declared that "Matters have become so bad, that if an adjudicator is honest, and he stands by his opinion, he is almost sure to be insulted if nothing worse happens to him, and one by one the self-respecting judges keep dropping out of the field" (October 
1897, 217). The editors of the journal, meanwhile, often maintained that the violence was on the part of supporters rather than the performers themselves. When a report appeared in the Yorkshire Post entitled "Disgraceful scene at a Band Contest," the editors of British Bandsman saw fit to reprint the article (October 1887, 25). In the ensuing issue (November 1887) the editors then added their own commentary on the situation: "...we may express our great regret at the unseemly proceedings at the close of the Saltaire Contest. We cannot believe the unsuccessful bands prompted or countenanced it" (38). Bailey notes the same emphasis on proper behavior and appropriate respect for middle class individuals in official reports from Working Men's Club and Institute Union (Popular Culture 41). This emphasis could result from a desire to see these activities succeed at their purpose, i.e. the reform of the working class; however, it is more likely an attempt to ease the social tension that existed in these situations. Brass bands served as a "cultural middle ground" (Herbert, "NineteenthCentury Bands," 33) where class boundaries were somewhat confused and social structure seemed tenuous.

Anxiety about brass band contests also revolved around the shifting status of the bandsman. The contest as a morally shaping activity was predicated on the notion that participants were working class and unaccustomed to the refinement of art music. Throughout the nineteenth and early twentieth centuries, writings about brass bands highlighted the working-class status of bandsmen. The review of the Manchester Guardian review of the inaugural Belle Vue contest noted that "when it is considered that all of the members, without exception, although upwards of one hundred, belonged to the working classes, and studied music, not professionally, but for recreation, the performances were in the highest degree creditable both to their taste and proficiency" (10 September 1853, 7). The British Bandsman later reported on one of England's most 
prominent composers of the time, Sir Arthur Sullivan, conducting a band in an arrangement of his own work. The composer commented, "Do you really mean to tell me that these men are working men? ... I am surprised, I can scare credit it. It is indeed wonderful" (February 1900, 43). This distinction of trained musician and working-class amateur was vital to banding as a morally-improving activity. When certain contest organizers decided to not include trained musicians in the process and instead opted to allow the audience (most likely made up of the working class) to decide the winner, the editors of Brass Band News were outraged:

$[\mathrm{W}] \mathrm{e}$ say, fearlessly, that there cannot be a band contest, in no wise whatsoever, unless an experienced musician of integrity and ability adjudicates upon the respective performances of each band; and to endeavor to organize musical competitions, with such thoroughly untrustworthy means of testing the competitors, is as undignified to the elements of musical art as it is pernicious to its general progress, and the only definition of which is - vulgar musical traffic. (February 1882,1$)$

Along similar lines, a reader of British Bandsman submitted the idea of using bandsmen rather than trained musicians, most often military bandmasters, as adjudicators. The editors responded:

A working man, with very little education, who devotes the greater part of his spare time to music, and especially if he becomes a decent performer, is greatly to be admired, and even honored, but directly he becomes arrogant and professes to know more about it than one who has been specially trained, and whose whole time is devoted to the practice of music, the sympathy of all self-respecting people falls from him. (November 1897, 258)

The emphasis in this passage is on trained musicians and their participation; without this middle-class participation, the entire contest is rendered meaningless, even offensive, to 
the middle-class editors.

Especially proficient musicians who emerged from the ranks of bands further confused the distinction of trained musician and amateur. Some were cognizant of this; Edwin Swift, a prominent brass band conductor in the nineteenth century, said that he was "a weaver by trade, and a professional musician by accident" (Brass Band News March 1904, 10). He left weaving at the age of 32 to pursue a conducting career, thereby moving from working-class bandsman to middle-class musician. A contemporary musician, Edwin Stead, won three Belle Vue competitions with the Meltham Mills Band; knowing that Meltham would be prohibited from competition for two years after their third victory, Stead proceeded to join the Black Dyke Mills Band and win the next three Belle Vue competitions, the only performer known to have pulled off the "hat trick" twice. Such musicians were the reason for the "bona fide" rule, which stipulated that players be members of their band for a number of months and did not perform professionally. Many groups found ways around the regulation. When bands were suspected of hiring professional players or bringing players in to the group at a late date, objections would be lodged with the judges, with varying degrees of success. In the case of one regional contest in 1903, a band that was disqualified for hiring two players from another band went so far as to bring the matter before a judge, who upheld the contest committee's decision. The editors of the Brass Band News commented, "The ... Band only did what is done by nearly all contesting bands. We doubt if there are a dozen first prizes won in all of England in one year by bands that have no outside help. It is very deplorable, but it is so" (December 1903, 4).

Brass bands fit in well with the Victorian notion of musical edification; it exposed working-class audiences to art music in a structured environment that encourage conformity and hierarchy, much like sport. The reality was more complex. 
Contests became so integral to brass bands that they were sites for conflict, where success became more important than the moral and artistic values that these events were supposed to promote. Rather than retreat from these activities, as with other rational recreations established by middle-class industrialists and entrepreneurs, the workingclass band members took a different route. The movement, as it began to be viewed, continued on its own separate trajectory from mainstream musical activity in England, existing in its own self-referential world. Declining membership certainly contributed to this transition; while numbers are notoriously difficult to verify, the peak of participation was most likely in the $1890 \mathrm{~s}^{10}$

Starting in 1913, the Crystal Palace competitions (having resumed as national competitions in 1900) commissioned original works to serve as test pieces in the contest. Rather than continue with arrangements of Western art music canonical works, brass bands began to develop a canonical repertoire of their own. A separate history developed alongside a separate repertoire. Early issues of Brass Band News included general features on canonical composers heard regularly in contests; composers such as Bach, Handel, Mozart, Mendelssohn, Meyerbeer, Gluck, and Beethoven all appeared in the journal. Later, features shifted to figures in the brass band movement: conductors Owen, Gladney, and Swift were the first to be featured. In 1904 a series of "reminiscences" of Belle Vue was published, which had at that time been running for more than fifty years. In 1894 the first of what would become the Brass Band Annual, a compilation of successful bands, where they had competed, and what they had won, was published as Sketches of Famous Bands. These annuals would complement the history found in other periodicals, forming a fully realized historical narrative of brass bands as a consolidated movement that did not need to lean on the art music canon or its history for legitimacy. The distinction between traditionally trained musician and bandsman 
became in many ways defunct, as the brass band world became a "movement" of its own. $^{11}$

One memory recounted to me during the course of my research was of Nat Snape, a stonemason who lived in the area of Whitefield, outside of Manchester. He played euphonium in the Besses o' th' Barn Band during the first part of the twentieth century, and during his tenure he had performed on tours that took him halfway around the world, including Australia and the United States. As he worked at his profession one day in front of some civic buildings, a gentleman of higher social status passed by, making a condescending comment. Nat would later recall to his friends that, while the comment had offended him, he smiled and was comforted with the knowledge that he had been places and done things that the well-to-do gentlemen would likely never experience. ${ }^{12}$ The brass band contest and the movement that formed around it came to enable forms of dignity, honor, pride, and community that did not depend on middleclass approval, adjudication or supervision. While class imagery continued, through the crucible of competition working-class band members became heroes, lionized in both regional populations and the larger community of the brass band world. The autonomy of the movement was representative of the developing autonomy of the working classes, and the idealized space of the contest became a refuge of equality, a world that rewarded effort in a world that treated the working classes differently.

\section{Notes}

[1] See especially Herbert (editor), The British Brass Band: A Musical and Social History; and Newsome, Brass Roots: A Hundred Years of Brass Bands and Their Music. While these works focus exclusively on the brass band tradition there is extensive work on Victorian music in general; the volumes edited by Bennett Zon, Nineteenth-Century British Music Studies, are among the best examples of this scholarship. This work focuses largely on 
composition and performance practices concerning art music, thereby focusing largely on the listening experiences of middle and upper class concert and church attendees. The large exceptions to this generalization, which are covered in Nineteenth-Century British Music Studies, are the studies that have been done on the music hall and the brass band movement.

[2] See especially Herbert.

[3] Art music is also referred to as "classical music," or as a cultivated tradition. Western art music revolves around a central canon of composers and replicated values of complexity, technical proficiency, and a lack of associations with a particular function or contemporary context. Music considered more "light" or "popular" in nature would be simpler, more accessible to the listener, and often tied to functions and contexts such as dance. This music was often referred to as "light" in that it was not perceived as conveying a depth of content, but was rather superficially appealing. The division between such a tradition and a more "popular" tradition was emerging during the nineteenth century with the development of the Western art canon.

[4] For a contemporary description of the history of brass band contests, see Jackson, "Origin and Promotion of Brass Band Contests," featured as a series in the Musical Opinion and Trade Review from 1895-1897. Jackson's unpublished biography also recounts a number of these events.

[5] See especially "Convivial Pleasures and Public Duties" in Tosh and "Other People, Other Values" in Walvin.

[6] See especially Rowbotham.

[7] In her discussion of middle-class anxieties, Laura Whelan examines middle-class perceptions of the working class; suburban residents needed the services that workingclass populations offered, yet sought to escape the perceived dangers of that group, creating lasting anxiety. Whelan notes that this is in no way reflective of the actual habits of the working class: "the anxiety about the safety and respectability of suburban space encountered in Victorian literature stemmed directly from the ways in which the urban poor were constructed in middle-class literature by the middle class themselves" (41).

[8] One example appears in the Brass Band News (April 1893, 9) from a Northern contributor dubbed "Trotter," who identifies clearly with the working class while not alienating middle-class participants and incorporating working-class language in a somewhat foreign manner: "The great cotton lock-out is over, and we're all going to work again... Strikes and lock-outs are hard things, barbarous things; but servility to wealth is contemptible, loathsome. In saying this I do not imply that we workers were right; I merely point out that Englishmen are still fighters, still capable of making all sacrifices for liberty, even to the death. During the struggle our bands have proved themselves 'true grit,' or, in words better understood in Lancashire, 'real jannock.' They have given their services freely for parades and concerts in aid of the distress, and have been the means of raising at least $£ 1000$, which I think a splendid result and something to be proud of."

[9] See Herbert, Appendix 3 for contest rules from the Crystal Palace competition (1902), the Belle Vue competition (1907), and the National Brass Band Championships of Great Britain (1989). The National Championship is the modern incarnation of the Crystal Palace contests; The Belle Vue contests have become the British Open Brass Band Championships.

[10] For more on this transition, see Russell, “'What is Wrong with Brass Bands?': Cultural Change and the Band Movement, 1918-c. 1964" in Herbert, editor, The British Brass Band.

[11] For more on the role of periodicals in the development of the brass band movement, see Odello.

[12] This story was conveyed to me on July 30, 2004 by Jim Cowburn, whose relation, Fred Cowburn, had been one of Nat's fellow performers in the Besses o' th' Barn Band between the times of the world tours, 1906-1911, and the 1940s. Fred Cowburn and Nat Snape helped to form the Besses Boys Band, of which Jim was an inaugural member in 1943. 


\section{Works Cited}

Archer, John E. “'Men Behaving Badly”?: Masculinity and the Uses of Violence, 18501900", in Everyday Violence in Britain, 1850-1950: Gender and Class, ed. Shani d'Cruze. England: Longman, 2000. 41-54. Print.

Bailey, Peter. Leisure and Class in Victorian England: Rational Recreation and the Contest for Control. London: Routledge, 1978. Print.

_-Popular Culture and Performance in the Victorian City. Cambridge: Cambridge University Press, 1998. Print.

Belle Vue Collection. Chethams Library, Manchester.

Cunningham, Hugh. Leisure in the Industrial Revolution: c. 1780-c. 1880. New York: St. Martin's Press, 1980. Print.

Hall, Donald, editor. Muscular Christianity: Embodying the Victorian Age. Cambridge: Cambridge University Press, 1994. Print.

Hailstone, Alf. The British Bandsman Centenary Book: A Social History of Brass Bands. Baldock, Hartfordshire: Egon Publishers, 1987. Print.

Hampson, Joseph. Origin, History and Achievements of the Besses O' th' Barn Band. Northampton: Jos. Rogers, 1893. Print.

Haweis, H. R. My Musical Memories. New York: Funk and Wagonells, 1884. Print.

_. Music and Morals. London, New York: Longmans, Green, and Co., 1896. Print.

Herbert, Trevor. "Victorian Brass Bands: Class, Taste, and Space", in The Place of Music: Music, Space, and the Production of Place, ed. Andrew Leyshon, David Matless, and George Revill. New York, London: Guilford and Longman, 1998. 104-128. Print.

"Nineteenth-Century Bands: Making a Movement", in The British Brass Band: A Musical and Social History, ed. Trevor Herbert. Revised edition. Oxford: Oxford University Press, 2000. 10-67. Print.

Hogarth, George. Musical History: Biography and Criticism. London: John W. Parker, 1835. Print.

Holt, Richard. Sport and the British: A Modern History. Oxford: Clarendon Press, 1990. Print.

Jackson, Enderby. "Origin and Promotion of Brass Band Contests." Musical Opinion and Trade Review 19, no. 222 (1895): 392-3, no. 223 (1895): 454-5, no 224 (1895): 538-9, no. 226 (1895): $673-5$, no. 228 (1895): $814-15$; 20 no. 230 (1896): 101-3, no. 232 (1896): 247-8, no. 234 (1896): 386-7, no. 238 (1896): 678-9; 21 no. 241 (1897): 37-8. 
Autobiography. Harry Mortimer Memorial Suite. Salford University. Photocopy.

Lee, Ying S. Masculinity and the English Working Class. New York and London: Routledge, 2007. Print.

Mangan, J. A. Athleticism in the Victorian and Edwardian School: the Emergence and Consolidation of an Educational Ideology. $3^{\text {rd }}$ edition. London: Frank Cass, 2000. Print.

'Manufactured' Masculinity: Making Imperial Manliness, Morality and Militarism. London: Routledge, 2012. Print.

editor. Making European Masculinities: Sport, Europe, Gender. London: Frank Cass, 2000. Print.

__ .'Muscular, Militaristic and Manly': The British Middle-Class Hero as Moral Messenger.” In European Heroes: Myth, Identity, and Sport, ed. Richard Holt, J.A. Mangan, and Pierre Lanfranchi. London: Frank Cass, 1996. 28-47. Print.

_- and James Walvin, editors. Manliness and Morality: Middle-class Masculinity in Britain and America 1800-1940. New York: St. Martin's Press, 1987. Print.

Mason, Tony, editor. Sport in Britain: A Social History. Cambridge: Cambridge University Press, 1989. Print.

Massey, Ron. Meltham and Meltham Mills Band: Celebrating 150 Years of Music, 1846-1996. No place of publication: 1996. Print.

Meller, H. E. Leisure and the Changing City, 1870-1914. London: Routledge, 1976.

Newsome, Roy. Brass Roots: A Hundred Years of Brass Bands and Their Music (1836-1936). Aldershot: Ashgate, 1998. Print.

Odello, Denise. "British Brass Band Periodicals and the Construction of a Movement." Victorian Periodicals Review 47:3 (2013), 432-453. Print.

Raynor, Henry. Music and Society Since 1815. London: Barrie and Jenkins, 1976. Print.

Rowbotham, Judith. '’Only When Drunk': The Stereotyping of Violence in England, c. 18501900." Everyday Violence in Britain, 1850-1950: Gender and Class, ed. Shani d'Cruze. England: Longman, 2000. 155-169. Print.

Russell, Dave. Popular Music in England, 1840-1914. Montreal, QC: McGill-Queen's University Press, 1987.

Scott, Jack. "The Evolution of the Brass Band and its Repertoire in Northern England." Diss. University of Sheffield, 1970. Print.

Tosh, John. A Man's Place: Masculinity and the Middle-Class Home in Victorian England. New Haven and London: Yale University Press, 1999. Print.

Tranter, Neil. Sport, Economy and Society in Britain 1750-1914. Cambridge: Cambridge University Press, 1998. Print.

Walvin, James. Victorian Values. Athens, Georgia: The University of Georgia Press, 1987. Print. 
Whelin, Laura Baker. Class, Culture and Suburban Anxieties in the Victorian Era. New York: Routledge, 2010. Print.

Zealley, Alfred Edward and J. Ord Hume. Famous Bands of the British Empire: Brief Historical Records of the Recognised Leading Military Bands and Brass Bands in the Empire. London: J. P. Hull, 1926. Print.

Zon, Bennett, ed. Ninteenth-Century British Music Studies. Aldershot, Brookfield VT: Ashgate, 2003. Print. 